7. Reprod. Fert. (1967) 13, 357-359

BRIEF COMMUNICATION

\title{
THE INDUCTION OF OVULATION IN THE SQUIRREL MONKEY (SAIMIRI SCIUREUS) WITH PREGNANT MARES SERUM (PMS) AND HUMAN CHORIONIC GONADOTROPHIN (HCG)
}

\author{
J. P. BENNETT \\ Biological Research Department, The British Drug Houses Ltd, \\ Godalming, Surrey
}

(Received 28th October 1966)

Successful induction of ovulation in some cyclic adult and prepubertal species of Old World monkey, Macacca mulatta, has been reported by Van Wagenen \& Simpson (1957) and by Simpson \& Van Wagenen (1962), using injected extracts of monkey pituitaries and human postmenopausal gonadotrophins respectively. In these studies ovulation was determined by histological examination of the ovary and no attempts were made to recover freshly ovulated eggs from the Fallopian tubes. Efforts to induce ovulation by injection of monkey pituitary were unsuccessful.

The first experiments are now reported of inducing ovulation, with injections of pregnant mares serum (PMS) and human chorionic gonadotrophin (HCG), in a species of New World monkey, Saimiri sciureus, the common squirrel monkey, as a step towards obtaining pregnancies in this species by artificial insemination.

It was impossible to obtain accurate information as to the stages of the reproductive cycle in these monkeys from examination of vaginal lavage and the injections of gonadotrophins were thus given without reference to the timing of their reproductive cycles; in contrast to the work of Van Wagenen \& Simpson (1957) and Simpson \& Van Wagenen (1962). The PMs (Pabryn-Paines \& Byrne Ltd) was injected subcutaneously into the lumbar region of mature females (600 to $700 \mathrm{~g}$ body weight) as a range of doses in distilled water, given twice daily (09.00 hours and 16.00 hours) for 9 consecutive days. During the last 4 days of these injections, the monkeys also received either 250 i.u. or 500 i.u. of HCG (Pregnyl-Organon) given concurrently with the PMS.

Several methods were used to observe ovulation and recover eggs from the Fallopian tubes after cessation of dosing. Initially, the ovaries were observed for fresh sites of ovulation by laparotomy on the afternoon of Day 11 or Day 12 from the commencement of dosing, using $0.25 \mathrm{ml} \mathrm{Nembutal}(60 \mathrm{mg} / \mathrm{ml}$ Abbott Laboratories) anaesthetic given intraperitoneally. In some monkeys, attempts were made to flush the eggs from the Fallopian tubes with normal saline while in 
situ, during laparotomy on Day 11. Complications due to the very small lumen of the isthmus and the general anatomy of the tract rendered the technique only partially successful.

Egg recoveries were obtained in other monkeys by complete removal of the reproductive organs on Day 12 and flushing the Fallopian tubes from either end with normal saline. The washings were collected into a watch glass and examined for eggs beneath a binocular microscope. The ovaries were examined for fresh ovulation sites, weighed, and then sectioned and stained for histological examination.

TABLE 1

THE NUMBERS OF OVULATION SITES PER OVARY AND OF EGGS RECOVERED FROM THE FALLOPIAN TUBES, AFTER INDUCTION OF OVULATION WITH SUBCUTANEOUS INJECTIONS OF PREGNANT MARE SERUM AND HUMAN GHORIONIG GONADOTROPHIN IN THE SQUIRREL MONKEY

\begin{tabular}{|c|c|c|c|c|c|c|c|c|}
\hline \multirow[t]{2}{*}{ Group } & \multicolumn{2}{|c|}{$\begin{array}{c}\text { Gonadotrophin dose (i.u.) } \\
\text { injected subcutaneously } \\
2 \times \text { day }(09.00 \text { and } 16.00 \text { hours })\end{array}$} & \multicolumn{2}{|c|}{$\begin{array}{c}\text { No. ovulation sites } \\
\text { /ovary }\end{array}$} & \multicolumn{2}{|c|}{$\begin{array}{l}\text { No. eggs recovered } \\
\text { from Fallopian tube }\end{array}$} & \multicolumn{2}{|c|}{$\begin{array}{c}\text { Ovarian weight } \\
(m g)\end{array}$} \\
\hline & $\begin{array}{c}\text { PMS } \\
\text { (Days 1-9) }\end{array}$ & $\begin{array}{c}\mathrm{HCG} \\
\text { (Days 5-9) }\end{array}$ & Left & Right & Left & Right & Left & Right \\
\hline A & $\begin{array}{r}200 \\
20 \\
2\end{array}$ & $\begin{array}{l}500 \\
500 \\
500\end{array}$ & $\begin{array}{l}8 \\
3 \\
0\end{array}$ & $\begin{array}{l}6 \\
4 \\
0\end{array}$ & $\begin{array}{l}0 \\
0 \\
-\end{array}$ & $\begin{array}{l}0 \\
4 \\
-\end{array}$ & $\overline{-}$ & $\overrightarrow{-}$ \\
\hline B & $\begin{array}{r}200 \\
20 \\
2\end{array}$ & $\begin{array}{l}250 \\
250 \\
250\end{array}$ & $\begin{array}{l}2 \\
1 \\
0\end{array}$ & $\begin{array}{l}0^{*} \\
6 \\
0\end{array}$ & $\begin{array}{l}1 \\
1 \\
0\end{array}$ & $\begin{array}{l}0 \\
2 \\
0\end{array}$ & $\begin{array}{r}104 \\
88 \\
37\end{array}$ & $\begin{array}{r}70 \\
130 \\
37\end{array}$ \\
\hline C & $\begin{array}{r}20 \\
10 \\
5\end{array}$ & $\begin{array}{l}250 \\
250 \\
250\end{array}$ & $\begin{array}{l}0 \\
3 \\
0\end{array}$ & $\begin{array}{l}1 \\
2 \\
0\end{array}$ & $\begin{array}{l}- \\
-\end{array}$ & $\begin{array}{l}- \\
\overline{-}\end{array}$ & $\overline{-}$ & $\begin{array}{l}- \\
-\end{array}$ \\
\hline
\end{tabular}

* Cystic ovary.

Group A. Egg recoveries obtained by flushing the Fallopian tubes in situ at laparotomy on Day 11.

Group B. Egg recoveries obtained by flushing the Fallopian tubes after removal from the animal at laparotomy on Day 12.

Group C. Ovaries examined on Day 12 at laparotomy. Egg recoveries not attempted.

The numbers of ovulation sites per ovary and the egg recovery values, following treatment, are shown in Table 1 together with the ovarian weights when noted. The ovulation sites at laparotomy appeared as small red protuberances on an otherwise smooth round ovary (Plate 1, a and f). Sections of ovaries after the gonadotrophin treatment are shown in Plate 1 (e) and (f), illustrating the very large follicle size at ovulation. Eggs recovered from the Fallopian tubes on the afternoon of Day 11 were found in the ampullae, embedded in cumulus (Plate 1b) but those recovered at the same time on Day 12 from other monkeys were free of cumulus and were located in the isthmus (Plate 1c).

Preliminary results indicated that the induced ovulation was an all-or-none process, the critical dose of PMs for the induction of ovulation lying between 5 and 10 i.u. injected twice daily. There was a marked increase in ovarian weight and size with increasing doses of PMs (Table 1). Reducing the dose of HCG by half did not markedly affect the number of induced ovulations. 
PLATE 1

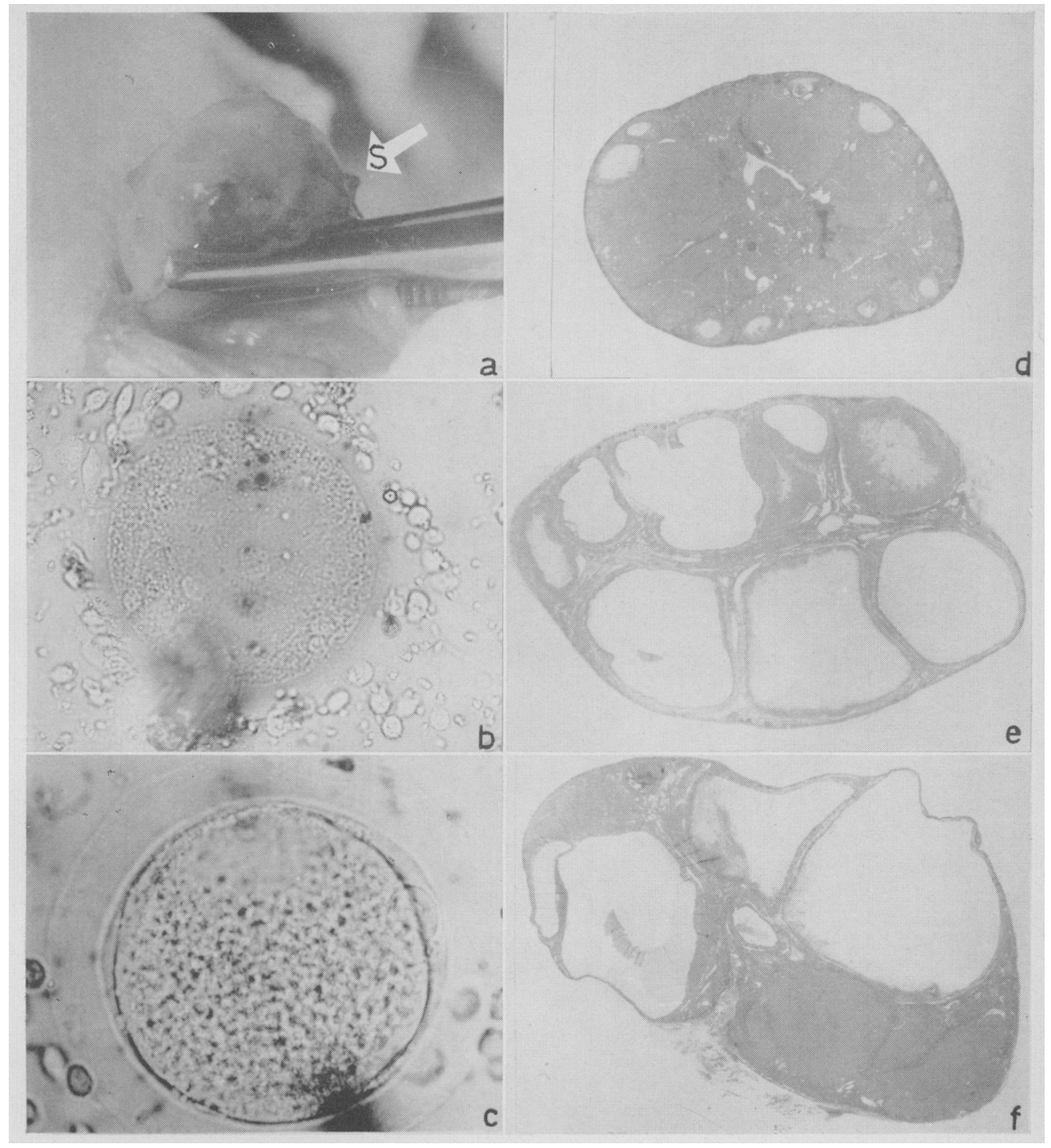

(a) Ovulation sites (s) upon the ovarian surface, after gonadotrophin induced ovulation of the squirrel monkey.

(b) A single cell squirrel monkey egg surrounded by cumulus cells, recovered from the ampulla $40 \mathrm{hr}$ after the cessation of gonadotrophin injections and stained with methylene blue $(\times 400)$. There is slight compression of the egg from the coverslip.

(c) A single cell squirrel monkey egg recovered from the isthmus $64 \mathrm{hr}$ after cessation of gonadotrophin injections and suspended in a hanging drop of normal saline $(\times 625)$.

(d) T.S. squirrel monkey ovary 3 days after receiving nine twice daily subcutaneous injections of 2 i.u. PMS together with 250 i.u. HCG given twice daily during the last 4 days of dosing with pMs $(\times 4 \cdot 5)$.

(e) T.S. squirrel monkey ovary 3 days after receiving nine twice daily subcutaneous injections of 20 i.u. PMs together with 250 i.u. HCG given twice daily during the last 4 days of dosing with PMS $(\times 4 \cdot 5)$.

(f) T.S. squirrel monkey ovary 3 days after receiving nine twice daily subcutaneous injections of 200 i.u. PMS together with $250 \mathrm{i}$.u. HCG given twice daily during the last 4 days of dosing with PMS $(\times 4 \cdot 5)$.

(Facing p. 358) 
Values for the egg recoveries were not very satisfactory. The uteri of the monkeys were, however, not searched for eggs in these experiments but methods of egg recovery from this organ are currently under study. Other results (Bennett, 1967) suggest, however, that the high levels of injected PMs cause acceleration in the transport of eggs from the Fallopian tubes into the uterus, probably from an elevated level of systemic oestrogen from the ovary acting upon the smooth muscle of the Fallopian tube. Accelerated tubal transport of eggs has been shown in superovulated cows (Rowson, 1951) and ewes (Robinson, 1951). This explanation for the egg losses from the superovulated squirrel monkey is under examination and studies are continuing into the artificial control of ovulation in the squirrel monkey.

\section{REFERENCES}

Bennetr, J. P. (1967) Artificial insemination of the squirrel monkey. F. Endocr. (In press).

Robinson, T. J. (1951) The control of fertility in sheep. II. The augmentation of fertility by gonadotrophin treatment of the ewe in the normal breeding season. 7. agric. Sci., Camb. 41, 6.

Rowson, L. E. A. (1951) Methods of inducing multiple ovulations in cattle. F. Endocr. 7, 260.

Simpson, M. E. \& VAN WAGENEN, G. (1962) Induction of ovulation with human urinary gonadotrophins in the monkey. Fert. Steril. 13, 140.

VAN WAgEnen, G. \& Simpson, M. E. (1957) Induction of ovulation in the Rhesus Monkey (Macacca mulatta). Endocrinology, 61, 316. 